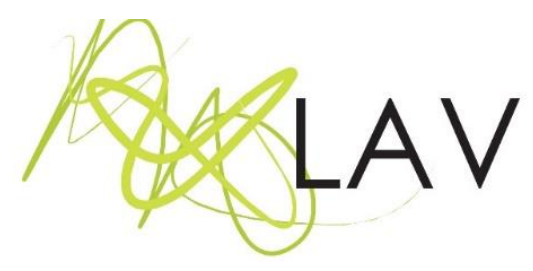

\title{
A profanação dos dispositivos escolares e o jogo teatral
}

The profanation of school devices and the theatrical game

Patrícia Neves de Almeidai

Instituto Federal de Educação, Ciência e Tecnologia de São Paulo

\begin{abstract}
Resumo
A investigação apresenta uma prática teatral realizada com alunos de uma escola da rede municipal de ensino, do município de Boituva-SP, e surge de uma inquietação em relação à presença dos dispositivos de controle na escola, mais particularmente de uma escada e sua regra que restringe o acesso dos alunos. A hipótese é de que o teatro, especificamente o jogo teatral de Spolin (2003) tem a potencialidade de operar o que Agamben (2007) nomeia uma "profanação". O estudo envolve a análise do conceito de dispositivo em Foucault (1979; 2004) e Agamben (2009); a descrição da prática intitulada "Experiência Teatral"; e a exposição dos relatos dos alunos, os quais revelam uma aproximação ao que se objetivava inicialmente: propiciar a reflexão sobre a existência dos dispositivos no cotidiano escolar, promovendo um novo uso deles, por meio da profanação da norma.
\end{abstract}

Palavras-chave: cotidiano escolar, dispositivo, profanação, jogo teatral.

\section{Abstract}

The research introduces a theatrical practice performed with students from a public school in the city of Boituva in São Paulo State, Brazil, and arises from a concern regarding the presence of control devices in the school, particularly from a stairway and its rule that restricts the students' access. The hypothesis is that the theater, specifically Spolin's theater game (2003), has the potential of operating what Agamben (2007) states as "profanation". The study involves the analysis of the concept of device in Foucault (1979; 2004) and Agamben (2009); the practice description, entitled "Theatrical Experience"; and the exposition of the student's reports on the devices, which disclose a bond in relation to what was the first objective: to enable to reflect upon the existence of the devices in the school daily life, promoting a new use to them, by the profanation of the rule.

Keywords: school daily life, device, profanation, theatrical games.

\section{Introdução}

A presente investigação possui abordagem qualitativa e tem como metodologia de pesquisa a modalidade pesquisa-ação, a qual é adequada neste contexto por ser, segundo Barbier (2007), pedagógica e política e servir à educação do sujeito, 
pertencendo à categoria da formação: "[...] um processo de criação de formas simbólicas interiorizadas, estimulado pelo sentido do desenvolvimento do potencial humano" (p. 19). Nessa modalidade, de acordo com o autor, o problema de pesquisa nasce em um contexto específico e o pesquisador "[...] não o provoca, mas constatao, e seu papel consiste em ajudar a coletividade a determinar todos os detalhes mais cruciais ligados ao problema, por uma tomada de consciência dos atores do problema numa ação coletiva" (BARBIER, 2007, p. 54).

Quanto à estrutura deste artigo, as seções estão divididas da seguinte maneira: em um primeiro momento, apresento o conceito de "Dispositivo" em Foucault (1979, 2004) e Agamben (2009), de "Profanação", com Agamben (2007) e o sistema de "Jogos Teatrais" de Spolin (2003); em seguida, exponho a origem do que nomeei "Experiência Teatral" e apresento uma descrição da prática realizada; e, finalmente, teço algumas considerações a respeito da investigação concluída.

\section{Foucault e o dispositivo}

Na obra 'Vigiar e Punir' (2004), ao investigar o papel das instituições (prisão, hospital, escola) Foucault utiliza a expressão 'dispositivos disciplinares', afirmando um conjunto de práticas que tem por objetivo a 'docilização dos corpos', tornando-os submissos e exercitados. A prisão com suas medidas de sofrimento físico; o hospital com sua vigilância das doenças e contágios; o exército com sua tropa dócil e útil; a escola com seus sujeitos disciplinados. Para Foucault, o corpo dócil é aquele que pode ser utilizado, transformado e aperfeiçoado.

O processo de disciplinamento dos corpos, no que concerne à escala, ao objeto e à modalidade, é assim entendido por Foucault (2004): em primeiro lugar, o controle se exerce sobre o corpo na sua individualidade, não se trata de cuidá-lo enquanto unidade inseparável da massa; em segundo, quanto ao objeto, o controle se exerce de modo a garantir a eficácia dos movimentos; e por último, o modo de atuação prevê uma coerção constante das atividades do corpo, interferindo no tempo, espaço e movimentos dos corpos. Para o pensador, as disciplinas são "[...] métodos que permitem o controle minucioso das operações do corpo, que realizam a sujeição constante de suas forças e Ihes impõem uma relação de docilidade-utilidade" ( $p$. 118), elas aumentam as forças do corpo, no que diz respeito à sua utilidade econômica, ao mesmo tempo em que promovem uma diminuição dessas mesmas forças, em termos políticos de obediência. O surgimento dessa política de controle não ocorreu de forma súbita, sua instauração se deve a uma grande multiplicidade

Revista Digital do LAV - Santa Maria - vol. 11, n. 1, p. 31-53 - jan./abr. 2018 ISSN 1983 - 7348 http://dx.doi.org/10.5902/1983734829659 
de processos mínimos, de origens distintas e localizações esparsas, que se repetem, se imitam, se apoiam e se diferem de acordo com o modo de aplicação.

Para que a disciplina atue é necessária a organização dos indivíduos no espaço. Assim, a primeira providência é encerrar as pessoas em um local fechado, cercá-las, para evitar a distribuição por grupos. "É preciso anular os efeitos das repartições indecisas, o desaparecimento descontrolado dos indivíduos, sua circulação difusa, sua coagulação inutilizável e perigosa" e ainda "[...] estabelecer as presenças e as ausências, saber onde e como encontrar os indivíduos, instaurar as comunicações úteis, interromper as outras, poder a cada instante vigiar o comportamento de cada um" (FOUCAULT, 2004, p. 123).

Pesquisando a relação entre corpo e escola no cotidiano escolar, Milstein e Mendes (2010) observaram que as regras e condutas consideradas adequadas na escola são internalizadas pelo aluno. Segundo eles:

Na maioria das situações vividas cotidianamente não são as reflexões nem as racionalizações que permitem que os sujeitos interpretem de modo imediato e atuem de maneira 'adequada'. É o sujeito-corpo que atua, posto que em seu corpo estão inscritas disposições, esquemas, matrizes [...] (MILSTEIN e MENDES, 2010, p. 27, grifo no original).

Ainda de acordo com os autores, que coadunam com os pressupostos de Foucault (2004), "[...] a corporização sempre supõe elaborações práticas de vínculos significativos com o espaço, o tempo, os objetos e os sujeitos que determinam interpretações práticas de situações" (MILSTEIN e MENDES, 2010, p. 27).

Para compreender de que forma os corpos são disciplinados, faz-se necessário a exposição do conceito de dispositivo.

A palavra 'dispositivo', como aponta Agamben (2009, p. 27) surge na obra de Foucault a partir da metade dos anos setenta. Antes o filósofo utilizava o termo 'positivité'. Segundo a 'Microfísica do Poder' (FOUCAULT, 1979, p. 246), "épistémè", era um outro termo que também se referia à ideia de dispositivo.

A alteração do termo é decorrente de um aprofundamento que Foucault faz sobre os elementos discursivos e não discursivos. A 'épistémè' referia-se, primeiramente, a dispositivos especificamente discursivos. Foucault passa a considerar a própria 
'épistémè' como um dispositivo e, a alteração do termo, passa a contemplar, também, os elementos não discursivos.

O dispositivo não discursivo é tratado por Foucault (2004), em 'Vigiar e Punir', no momento em que desenvolve o conceito de vigilância e usa o 'Panóptico de Bentham' como ilustração dessa ideia. O projeto de Bentham diz respeito a uma construção em forma de anel, contendo no centro uma torre; há diversas celas com janelas que dão para o interior e exterior da construção; a luz atravessa a cela de lado a lado; na torre, um vigia pode ver todas as celas, sem que os prisioneiros o vejam. Esse é o princípio do Panóptico: um estado permanente de visibilidade que garante o funcionamento do poder.

A vigilância gera, de acordo com Muchail (2004), o controle do tempo e dos corpos e a instalação de um poder polimorfo. O controle do tempo se dá a todo momento e em todas as instituições disciplinares, "controlados são os tempos de festa, de prazer, de ociosidade, de descanso" (p. 66). O mesmo ocorre com o corpo, que deve ser "[...] formado, reformado, corrigido, o que deve adquirir aptidões, receber um certo número de qualidades, qualificar-se como corpo capaz de trabalhar" (FOUCAULT apud MUCHAIL, 2004, p. 67). Já o poder polimorfo é instaurado pelas instituições disciplinares (fábrica, escola, prisão, hospital), visto que o poder se desdobra em aspectos econômicos, políticos, judiciários e epistemológicos.

Na essência de toda disciplina, funciona um mecanismo de penalidade. Foucault (2004) chama de 'sanção normalizadora' a particularidade que a disciplina tem de qualificar e reprimir os comportamentos. Assim, as instituições disciplinares operam

[...] micropenalidades do tempo (atrasos, ausências, interrupções das tarefas), da atividade (desatenção, negligência, falta de zelo), da maneira de ser (grosseria, desobediência), dos discursos (tagarelice, insolência), do corpo (atitudes "in-corretas", gestos não conformes, sujeira), da sexualidade (imodéstia, indecência). Ao mesmo tempo é utilizada, a título de punição, toda uma série de processos sutis, que vão do castigo físico leve a privações ligeiras e a pequenas humilhações (FOUCAULT, 2004, p. 149).

Outra particularidade da disciplina, segundo Foucault (2004), é o 'exame', que permite qualificar, classificar e punir. Ele possibilita a constituição do sujeito como um objeto que pode ser descrito e analisado, mantendo-o na sua evolução particular, ao mesmo tempo, promove a comparação dos indivíduos de um grupo. 
Na obra 'Microfísica do Poder', Foucault (1979) define aquilo que passou a chamar de dispositivo e assinala suas particularidades:

\begin{abstract}
Através deste termo tento demarcar, em primeiro lugar, um conjunto decididamente heterogêneo que engloba discursos, instituições, organizações arquitetônicas, decisões regulamentares, leis, medidas administrativas, enunciados científicos, proposições filosóficas, morais, filantrópicas. Em suma, o dito e o não dito são os elementos do dispositivo. $O$ dispositivo é a rede que se pode estabelecer entre estes elementos (FOUCAULT, 1979, p. 244).
\end{abstract}

Quanto à natureza da relação que existe entre esses elementos, Foucault (1979) crê que determinado discurso pode servir como justificativa para mascarar certas práticas, ou como reinterpretação das mesmas, havendo um jogo em que ocorrem mudanças de posição e de função. Para o pensador, o dispositivo surge para responder a uma urgência e por isso desempenha um papel estratégico dominante.

No que concerne ao saber, Foucault (1979, p. 246) afirma que o dispositivo "[...] está sempre inscrito em um jogo de poder [...] ligado a uma ou a configurações de saber que dele nascem, mas que igualmente o condicionam". Conclui que o dispositivo é: "[...] estratégias de relações de força sustentando tipos de saber e sendo sustentadas por eles" (FOUCAULT, 1979, p. 246). O pensador compreende essa relação dentro da lógica de 'negação da hipótese repressiva', a qual é apresentada na obra 'História da sexualidade I: a vontade de saber' (FOUCAULT, 1993). Segundo ele, os dispositivos não são, necessariamente, derivados de uma repressão fundamental e vitoriosa. Para Foucault (1993, p. 71):

Trata-se, portanto, de levar a sério esses dispositivos e de inverter a direção da análise: ao invés de partir de uma repressão geralmente aceita e de uma ignorância avaliada de acordo com o que supomos saber, é necessário considerar esses mecanismos positivos, produtores de saber, multiplicadores de discursos, indutores de prazer e geradores de poder. É necessário segui-los nas suas condições de surgimento e de funcionamento e procurar de que maneira se formam, em relação a eles, os fatos de interdição ou de ocultação que Ihes são vinculados. Em suma, trata-se de definir as estratégias de poder imanentes a essa vontade de saber.

Assim, o filósofo nos convida a pensar a relação entre 'saber' e 'poder' a partir da investigação do dispositivo, e não do poder repressor em si. Para tanto, faz-se necessário o conhecimento de sua origem, função e formas pelas quais produz e multiplica o 'saber'. 


\section{Agamben e a profanação do dispositivo}

Na obra 'O que é o contemporâneo? E outros ensaios', Agamben (2009) apresenta a origem do conceito foucaultiano de dispositivo, antes de propor um novo uso para o termo.

Segundo Agamben, a palavra "dispositivo" surge em substituição à palavra "positivité" (positividade), usada primeiramente por Hegel para denominar o elemento histórico "[...] com toda sua carga de regras, ritos e instituições impostas aos indivíduos por um poder externo [...]" (2009, p. 32). Foucault utiliza a 'positivité' para investigar a relação entre o sujeito e o elemento histórico, propondo uma mudança de enfoque: diferente de Hegel que pretendia reconciliar os dois elementos, o objetivo de Foucault é investigar de que modo as positividades (os dispositivos) agem nas relações humanas, nos jogos de poder.

No intuito de aproximar o significado do termo e o conceito foucaultiano, Agamben (2009) recorre à gênese da palavra dispositivo, utilizando para tanto a ideia do termo grego 'oikonomia'. Nos primeiros séculos da Igreja Católica, era primordial definir a Santíssima Trindade, já que a existência das três figuras 'Pai, Filho e Espírito Santo' podia reintroduzir o politeísmo e, assim, o paganismo. Logo, a solução foi disseminar o entendimento de que Deus, na sua substância, é uno, enquanto a sua 'oikonomia' (administração do mundo) é tríplice. A tradução da palavra "oikonomia" pelos padres latinos é "dispositio" e nomeia "[...] aquilo em que e por meio do qual se realiza uma pura atividade de governo sem nenhum fundamento no ser. Por isso os dispositivos devem sempre implicar um processo de subjetivação, isto é, devem produzir o seu sujeito" (AGAMBEN, 2009, p. 38). Portanto, a "oikonomia" é "[...] um conjunto de práxis, de saberes, de medidas, de instituições cujo objetivo é gerir, governar, controlar e orientar, num sentido que se supõe útil, os gestos e os pensamentos dos homens" (p. 39).

Aprofundando o conceito de dispositivo na produção de subjetividades, Agamben (2009) propõe situar o dispositivo em um novo contexto. Para isso, divide o existente em duas grandes classes: os seres viventes e os dispositivos e, entre eles, como resultando da interação, os sujeitos. Partindo dessa relação, sugere uma nova compreensão do dispositivo:

Generalizando posteriormente a já bastante ampla classe dos dispositivos foucaultianos, chamarei literalmente de dispositivo qualquer coisa que tenha de algum modo a capacidade de capturar, orientar, determinar, interceptar,

Revista Digital do LAV - Santa Maria - vol. 11, n. 1, p. 31-53 - jan./abr. 2018 ISSN 1983 - 7348 
modelar, controlar e assegurar os gestos, as condutas, as opiniões e os discursos dos seres viventes. Não somente, portanto, as prisões, os manicômios, o Panóptico, as escolas, a confissão, as fábricas, as disciplinas, as medidas jurídicas etc., cuja conexão com o poder é num certo sentido evidente, mas também a caneta, a escritura, a literatura, a filosofia, a agricultura, o cigarro, a navegação, os computadores, os telefones celulares e - por que não - a própria linguagem, que talvez é o mais antigo dos dispositivos, em que há milhares e milhares de anos um primata - provavelmente sem se dar conta das consequências que se seguiriam - teve a inconsciência de se deixar capturar (AGAMBEN, 2009, p. 40).

Comparando a denominação de Agamben (2009) e a definição de Foucault (1979) acerca do dispositivo, é possível notar que Agamben desenvolve o conceito, agregando outros modos, meios e práticas de controle. Enquanto Foucault pensava nas instituições, nas organizações arquitetônicas, nas leis e medidas administrativas, nos discursos, nos enunciados científicos e nas proposições filosóficas, Agamben abarca qualquer coisa que tenha o poder de captura, seja ela um objeto, um instrumento, uma máquina, ou a própria linguagem.

Nessa perspectiva, pelas novas formas de relação entre os seres viventes e os dispositivos, há a impressão de que os processos de subjetivação se alteram. Entretanto Agamben (2009) observa que

Ao ilimitado crescimento dos dispositivos no nosso tempo corresponde uma igualmente disseminada proliferação de processos de subjetivação. Isso pode produzir a impressão de que a categoria da subjetividade no nosso tempo vacila e perde consistência; mas se trata [...] de uma disseminação que leva ao extremo o aspecto de mascaramento que sempre acompanhou toda identidade pessoal (AGAMBEN, 2009, p. 41).

Desse modo, vivemos rodeados por dispositivos que nos controlam e orientam a todo o tempo e, ainda assim, temos a falsa impressão de que esses dispositivos não geram processos de subjetivação. Ocorre que todo dispositivo nasce do desejo humano de felicidade e, para Agamben (2009) "[...] a captura e a subjetivação deste desejo, numa esfera separada, constituem a potência específica do dispositivo" (p. 44).

A presença dos dispositivos que regulamentam e orientam a vida, se justificam por uma tendência contemporânea de tornar regra a exceção (AGAMBEN, 2004). Assim, nos deparamos com uma série de situações, equipamentos, discursos, que seriam destinados àqueles que de alguma maneira transgrediram a regra. Ocorre que, no estado de exceção permanente todos são culpados até que se prove o contrário. 
O que fazer então? O filósofo nos aconselha: profanar! "A profanação é o contradispositivo que restitui ao uso comum aquilo que o sacrifício tinha separado e dividido" (AGAMBEN, 2009, p. 45). Para Agamben (2009) profanar é devolver ao uso comum aquilo que foi separado na esfera do sagrado, é dar um novo uso.

Para compreender em que consiste a proposta do filósofo, faz-se necessário, primeiramente, distinguir o sagrado do profano:

Sagradas ou religiosas eram as coisas que de algum modo pertenciam aos deuses. Como tais, elas eram subtraídas ao livre uso e ao comércio dos homens, não podiam ser vendidas nem dadas como fiança, nem cedidas em usufruto ou gravadas de servidão. Sacrilégio era todo ato que violasse ou transgredisse esta sua especial indisponibilidade, que as reservava exclusivamente aos deuses celestes (nesse caso eram denominadas propriamente 'sagradas') ou infernais (nesse caso eram simplesmente chamadas 'religiosas'). E se consagrar (sacrare) era o termo que designava a saída das coisas da esfera do direito humano, profanar, por sua vez, significava restituí-las ao livre uso dos homens (AGAMBEN, 2007, p. 65).

Para Agamben (2007, p. 66) a religião é o elemento que realiza a separação entre sagrado e profano. Ele mostra que a palavra religião não deriva de religare, e sim de relegere que "indica a atitude de escrúpulo e de atenção que deve caracterizar as relações com os deuses [...] as fórmulas que se devem observar a fim de respeitar a separação entre o sagrado e o profano", portanto a religião não é o que une homens e deuses, mas o que separa.

Agamben (2007, p. 71) acredita que o capitalismo "generaliza e absolutiza, em todo âmbito, a estrutura da separação que define a religião. Onde o sacrifício marcava a passagem do profano ao sagrado [...] está agora um único, multiforme e incessante processo de separação" e por essa característica a religião capitalista 1 "está voltada para a criação de algo absolutamente Improfanável". Assim, Agamben acredita que a passagem do sagrado ao profano pode se dar por meio de um uso impróprio do sagrado: pelo jogo! De acordo com o filósofo o sagrado e o jogo estão estreitamente vinculados, pois

A maioria dos jogos que conhecemos deriva de antigas cerimônias sacras, de rituais e de práticas divinatórias que outrora pertenciam à esfera religiosa em sentido amplo. Brincar de roda era originalmente um rito matrimonial; jogar

\footnotetext{
${ }^{1} \mathrm{O}$ autor faz referência a um fragmento de Walter Benjamin, escrito em 1921, intitulado 'O Capitalismo como Religião'.
}

Revista Digital do LAV - Santa Maria - vol. 11, n. 1, p. 31-53 - jan./abr. 2018 ISSN 1983 - 7348

http://dx.doi.org/10.5902/1983734829659 
com bola reproduz a luta dos deuses pela posse do sol; os jogos de azar derivam de práticas oraculares; o pião e o jogo de xadrez eram instrumentos de adivinhação (AGAMBEN, 2007, p. 66).

O jogo pode libertar o humano da esfera do sagrado, mas seu uso, segundo Agamben (2007, p. 67) é especial, pois não tem a ver apenas com a religião: "As crianças, que brincam com qualquer bugiganga que Ihes caia nas mãos, transformam em brinquedo também o que pertence à esfera da economia, da guerra, do direito e das outras atividades que estamos acostumados a considerar sérias". Entretanto, nos deparamos com o declínio da utilização do jogo como instrumento profanatório, já que o homem contemporâneo não sabe jogar. Acrescenta-se a isso a criação do que Agamben chama de "jogos televisivos de massa", os quais possuem "uma intenção inconscientemente religiosa", de separação (2007, p. 68). Por essa razão, o filósofo acredita que é uma tarefa política devolver ao jogo sua vocação profana.

Prosseguindo com a investigação, Agamben trata da secularização, que também sugere uma transferência, mas se distingue da profanação. Para o autor:

A secularização é uma forma de remoção que mantém intactas as forças, que se restringe a deslocar de um lugar a outro. Assim, a secularização política de conceitos teológicos (a transcendência de Deus como paradigma do poder soberano) limita-se a transmutar a monarquia celeste em monarquia terrena, deixando, porém, intacto o seu poder.

A profanação implica, por sua vez, uma neutralização daquilo que profana. Depois de ter sido profanado, o que estava indisponível e separado perde a sua aura e acaba restituído ao uso. Ambas as operações são políticas, mas a primeira tem a ver com o exercício do poder, o que é assegurado remetendoo a um modelo sagrado; a segunda desativa os dispositivos do poder (AGAMBEN, 2007, p. 68).

A desativação dos dispositivos do poder depende do novo uso que fazemos deles, mas o que é exatamente 'fazer um novo uso'? Agamben (2007) nos traz o exemplo do gato. Ao brincar com um novelo como se fosse um rato, o gato usa sua atitude predatória. No novo uso que faz, o gato não cancela seu comportamento natural, mas devido a substituição do rato pelo novelo, há por consequência uma desativação desse comportamento predatório.

O novo uso liberta os comportamentos de um fim, nas palavras do autor "O comportamento libertado [...] reproduz e ainda expressa gestualmente as formas da atividade de que se emancipou, esvaziando-as, porém, de seu sentido e da relação 
imposta com uma finalidade, abrindo-as e dispondo-as para um novo uso" (p. 74). Assim, o resultado dessa atividade é um 'meio puro', uma prática que conserva sua natureza mas se desprende de um objetivo. Para o autor, só se pode fazer um novo uso desativando o velho uso. Entretanto, a esfera dos meios puros é frágil, como o jogo que é temporário, "[...] depois do qual a vida normal deve retomar seu curso (e o gato a sua caça)" (p. 75).

O capitalismo age sobre os meios puros, que são, por natureza, comportamentos profanatórios. A linguagem, com seu potencial de profanação é um exemplo disso: "Os dispositivos midiáticos têm como objetivo, precisamente, neutralizar esse poder profanatório da linguagem como meio puro, impedir que o mesmo abra a possibilidade de um novo uso, de uma nova experiência da palavra" (AGAMBEN, 2007, p. 76).

Mas, se o capitalismo captura a linguagem e o jogo e, se ele próprio é improfanável, o que fazer? A resposta vem com Agamben (2007, p. 79): "[...] é importante toda vez arrancar dos dispositivos - de todo dispositivo - a possibilidade de uso que os mesmos capturaram".

Em 'Profanações', Agamben (2007) ao mencionar a captura dos 'meios puros' (comportamentos profanatórios) pelo capitalismo, explicita a potencialidade que a linguagem tem de profanar:

Se os dispositivos do culto capitalista são tão eficazes é porque agem não apenas e nem sobretudo sobre os comportamentos primários, mas sobre os meios puros, ou seja, sobre comportamentos que foram separados de si mesmos e, assim, separados da sua relação com uma finalidade. Na sua fase extrema, o capitalismo não é senão um gigantesco dispositivo de captura dos meios puros, ou seja, dos comportamentos profanatórios. Os meios puros, que representam a desativação e a ruptura de qualquer separação, acabam por sua vez sendo separados em uma esfera especial. Exemplo disso é a linguagem. Certamente o poder sempre procurou assegurar o controle da comunicação social, servindo-se da linguagem como meio para difundir a própria ideologia e para induzir a obediência voluntária. Hoje, porém, tal função instrumental ainda eficaz às margens do sistema, quando se verificam situações de perigo e de exceção - deu lugar a um procedimento diferente de controle, que, ao ser separado na esfera espetacular, atinge a linguagem no seu rodar no vazio, ou seja, no seu possível potencial profanatório (AGAMBEN, 2007, p. 76). 
Adotarei, nesta pesquisa, a definição de Agamben (2009) acerca do dispositivo, por abarcar qualquer coisa que tenha a finalidade de controlar e orientar, mas, sobretudo, por compreender a linguagem. Dado o potencial profanatório da linguagem, considero que a proposta da 'Experiência Teatral', que será apresentada nesta pesquisa, pode se configurar como uma possibilidade de profanação dos dispositivos de controle presentes no ambiente escolar, ainda que se valendo de um dispositivo: o Teatro.

\section{Spolin e o Jogo Teatral}

Na obra 'Improvisação para o teatro', publicada originalmente em 1963, Spolin (2003) apresenta minuciosamente o sistema de Jogos Teatrais, o qual se justifica, nesta pesquisa, por ser a metodologia adotada na parte prática da investigação. A autora fala em 'sete aspectos da espontaneidade' que podem auxiliar tanto aluno quanto professor a ter liberdade pessoal na linguagem teatral, são eles: Jogos, Aprovação/Desaprovação, Expressão de Grupo, Plateia, Técnicas Teatrais, Transposição do processo de aprendizagem para a vida diária e Fisicalização. Explanarei acerca dos seis primeiros aspectos, os quais dialogam efetivamente com a proposta da 'Experiência Teatral'.

No que se refere aos Jogos e às Técnicas Teatrais, Spolin (2003) crê que "O jogo é uma forma natural de grupo que propicia o envolvimento e a liberdade pessoal necessários para a experiência. Os jogos desenvolvem as técnicas e habilidades pessoais necessárias para o jogo em si, através do próprio ato de jogar" (p. 4). Assim, as técnicas teatrais não estão separadas da experiência, elas são aprendidas na vivência do jogo. Ainda sobre os Jogos, a autora explica que

O objetivo no qual o jogador deve constantemente concentrar e para o qual toda ação deve ser dirigida provoca espontaneidade. Nessa espontaneidade, a liberdade pessoal é liberada, e a pessoa como um todo é física, intelectual e intuitivamente despertada. Isto causa estimulação suficiente para que o aluno transcenda a si mesmo - ele é libertado para penetrar no ambiente, explorar, aventurar e enfrentar sem medo todos os perigos (SPOLIN, 2003, p. 5).

Nesse ambiente de experimentação, o instrutor do jogo deve eliminar a aprovação e a desaprovação, que mina a liberdade pessoal do jogador. No processo de aprendizagem da linguagem teatral, Spolin (2003) aconselha:

Uma vez que muitos de nós fomos educados pelo método da aprovação/desaprovação, é necessário uma constante autoobservação por parte do professor-diretor para erradicar de si

Revista Digital do LAV - Santa Maria - vol. 11, n. 1, p. 31-53 - jan./abr. 2018 ISSN 1983 - 7348 
mesmo qualquer manifestação desse tipo, de maneira que não entre na relação professor-aluno (SPOLIN, 2003, p. 7).

Para que a improvisação ocorra é necessário um grupo de pessoas trabalhando coletivamente na solução do problema de atuação, por isso Spolin (2003, p. 9) argumenta que a atuação está intrinsecamente ligada à relação com os outros integrantes do grupo, porque "o teatro improvisacional requer relacionamento de grupo muito intenso, pois é a partir do acordo e da atuação em grupo que emerge o material para as cenas e peças".

No que concerne à plateia, Spolin (2003, p. 11) acredita que ela "deve se tornar uma parte concreta do treinamento teatral". Acontece que em muitas práticas do teatro tradicional há uma instrução de "esquecer a plateia" ou "criar uma quarta parede". A autora considera a plateia "o membro mais reverenciado do teatro", o que dá significado à peça. Coaduno com a ideia de que

[...] cada membro da plateia deve ter uma experiência pessoal, não uma estimulação artificial, enquanto assiste à peça. Quando a plateia toma parte neste acordo de grupo, ela não pode ser pensada como uma massa uniforme a ser empurrada ou atrelada pelo nariz, nem deve viver a vida de outros (mesmo que seja por uma hora), nem se identificar com os atores e representar através deles emoções cansadas e gratuitas. A plateia é composta de indivíduos diferenciados que estão assistindo à arte dos atores (e dramaturgos), e é para todos eles que os atores (e dramaturgos) devem utilizar suas habilidades para criar o mundo mágico da realidade teatral. Este deveria ser um mundo onde todo problema humano, enigma ou visão, possa ser explorado (SPOLIN, 2003, p. 12).

O último aspecto da espontaneidade diz respeito à transposição do processo de aprendizagem para a vida diária, e creio que este seja o elemento que melhor ilustra a contribuição do sistema de jogos teatrais para a Educação:

Quando o aluno vê as pessoas e as maneiras como elas se comportam quando juntas, quando vê a cor do céu, ouve os sons no ar, sente o chão sob seus pés e o vento em sua face, ele adquire uma visão mais ampla de seu mundo pessoal e seu desenvolvimento como ator é acelerado. O mundo fornece o material para o teatro, e o crescimento artístico desenvolvese par e passo com o nosso reconhecimento e percepção do mundo e de nós mesmos dentro dele (SPOLIN, 2003, p. 13).

É possível observar, pelas citações feitas até aqui, que Spolin (2003, p. 13) fala de uma exploração do aparato sensorial e de uma aprendizagem do mundo em nível físico. Isso não significa que o ato de jogar limite a aprendizagem ao plano do 
sensível. O "reconhecimento e percepção do mundo e de nós mesmos dentro dele" também ocorre no nível intelectual.

\section{A origem da 'Experiência Teatral'}

São sete horas. Busco os alunos do $9^{\circ}$. A na fila e subo com eles, pela escada deles: à esquerda. À direita, uma inspetora protege a 'escada dos professores'. Quem ameaça avançar pela direita é afastado aos berros. Ao primeiro descuido da funcionária, um aluno sobe correndo pela escada 'errada', zombando da careta que recebe. Não contente, a funcionária sobe a escada em busca do desobediente e o faz descer e subir novamente, agora pela escada 'certa'.

Na sala, peço aos alunos que formem um círculo e pergunto a eles: o que incomoda vocês na escola? No primeiro momento recebo silêncio e expressões de dúvida. Em seguida, respostas confusas. Uma aluna comenta a falta de livros de seu interesse na biblioteca; outra reclama do tempo para comer; alguém maldiz uma professora; um considera pouca a quantidade de linhas para respostas na apostila. E o que mais? Silêncio e timidez. Meus alunos são extremamente disciplinados. A turma do $9^{\circ}$. A, não por acaso se pensarmos no ' $A$ ' que a identifica, é considerada pelos professores a 'melhor sala'. Em consequência, possui os 'melhores alunos', os mais obedientes, os que fazem as tarefas e os mais informados. Então, os escolho para realizar a minha proposta.

Tomando o cuidado de não realizar uma abordagem tendenciosa com meus alunos, inicio na sala de aula conversas informais, que geram um conhecimento e uma crítica dos procedimentos correntes na escola. Essa prática é conhecida como conversa não diretiva, por meio dela o levantamento de dados é feito a partir do livre discurso.

Nas conversas que realizei com meus alunos, foram elencadas diversas situações e discursos disciplinadores, considerados por eles infundados ou, pelo menos, mal esclarecidos. Eles citaram:

-As proibições de boné e celular:

Eles falam que a gente tá com fone de ouvido escondido pra escutar música, acham que a gente tá escondendo droga na touca... (Aluna C, 14 anos, 90. A).

Falam que se você for procurar um emprego usando boné, ninguém vai empregar, porque pensa que você é um marginal (Aluna D, 14 anos, 90. A). 
-A obrigatoriedade do uniforme completo:

A gente passa a maior parte da nossa vida na escola e não pode nem ter personalidade e usar a roupa que quer (Aluna $D, 14$ anos, 9०. A).

-O corredor de entrada estreito:

É como se fosse uma boiada, tem um pequeno portão e daí vai entrando todo mundo em filinha (Aluna $C, 14$ anos, $9^{\circ} . A$ ).

Tem dois lugares pra sair e a gente tem que sair por um só, se matando. Eu, toda vez que saio daqui chego lá na frente sem tênis (Aluna E, 15 anos, 90. A).

-O sinal;

-A fila:

Não precisa. Tão querendo tratar a gente que nem animal (Aluno F, 14 anos, 90. A).

-O mapa de sala (que determina onde cada aluno deve se sentar):

Eu sento sempre no mesmo lugar, só que tem algumas aulas que eu vou pra outro lugar conversar com o pessoal, ou fazer lição. Alguns professores reclamam e já chegam gritando 'cada um pro seu lugar, tem um minuto e já passou meio' (Aluna G, 14 anos, 90. A).

-As cópias intermináveis:

Copiar capítulos inteiros da apostila, um atrás do outro, sendo que tem na apostila as páginas pra gente resolver. 'Ela' manda copiar e responder no caderno e ainda resolver na apostila (Aluna $E, 15$ anos, 90. A).

-O discurso irônico e vexatório de alguns professores, funcionários e gestores:

O professor explica na lousa, daí pergunta se a gente entendeu. Mas na hora de fazer, às vezes a gente não sabe na prática. E se a gente vai perguntar 'ele' é super ignorante em dizer 'você não prestou atenção na hora da explicação?' (Aluna C, 14 anos, 90. A).

-Não poder entrar na sala no período do intervalo; 
-Não poder comer sentado na arquibancada;

-Não mascar chiclete;

-As ordens de não falar e não levantar:

Algumas regras atrapalham a própria Educação (Aluno H, 14 anos, 90. A).

-Não poder ir ao banheiro na primeira, terceira e quarta aula (respectivamente os discursos 'o aluno acabou de chegar na escola', 'o aluno já vai sair para o intervalo' e 'o aluno acabou de chegar do intervalo');

É verdade que tem gente que vai no banheiro só pra passear (Aluna G, 14 anos, $9^{\circ}$. A).

Mas mesmo assim. De vez em quando o aluno tá estressado, ou traz uns problemas de casa, pra não ficar aliviando aqui na sala, tem que sair mesmo (Aluno $F, 14$ anos, 90. A).

-O curto tempo de intervalo:

Você vem pra escola pra estudar. Por isso o tempo de intervalo é pouco: pra você não comer e pra você não ter o tempo de refletir em nada no intervalo (Aluna $C, 14$ anos, $\left.9^{\circ} . A\right)$.

Dentre todos os disciplinamentos absurdos citados pelos alunos, o mais marcante para mim diz respeito à proibição de subir a escada pelo lado direito, destinado aos professores:

Os alunos deveriam descer pelas duas (escadas), porque depois vão dizer 'ah, fulano empurrou fulano', mas por que? Porque a gente só pode descer por uma escada. Fica todo mundo amontoado lá. É estranho ter duas escadas, uma só para os professores e outra para os alunos. Tem 10 professores pra 200 alunos (Aluna G, 14 anos, 90. A).

Por que tem essa preferência? Na teoria eles querem deixar um ambiente mais confortável. Mas não dá. O lance da escada atrapalha, pois nós somos em maior número de pessoas, e aí fica muito apertado o espaço (Aluno F, 14 anos, 90. A).

A gente sente que somos diferentes deles (Aluna G, 14 anos, 90. A). 
Superioridade e inferioridade (Aluna $A, 14$ anos, 90. A).

Às vezes você já tinha descido e te mandavam voltar dizendo 'você vai voltar porque você sabe que não é por aqui'. Até quando desce uma classe por vez, tem que descer pela 'escada dos alunos', não pode descer pela 'escada dos professores' (Aluna G, 14 anos, 90. A).

Você vê aquela pessoa olhando pra você, apontando o dedo na sua cara e falando 'você não vai subir porque senão vai para a diretoria'. Poxa, eu não posso subir por esta escada? Mas a escada não é de todo mundo? (Aluna A, 14 anos, 90. A).

Inspirada por tantos despropósitos, criei um roteiro cênico que tinha como conteúdo os 'disciplinamentos', que a partir daqui e, acompanhada de Agamben (2009), chamarei de dispositivos. Esse roteiro possibilitava o jogo e o improviso pelos alunos, diferente de uma proposição com um texto pré-estabelecido que poderia minar o processo criativo dos alunos ao mesmo tempo em que imporia um discurso a eles (talvez o meu discurso). Assim, a partir das conversas iniciais, organizei os dispositivos que iríamos discutir na prática, sugerindo espaços de atuação e jogos, pelo roteiro cênico. De posse do roteiro (o qual foi apresentado de forma oral, de modo mais espontâneo) e de instruções de jogos, os alunos passaram a improvisar situações inspiradas no cotidiano escolar.

Intitulei o trabalho de 'Experiência Teatral'. Como a cidade tem uma cena teatral ainda tímida e a apreciação ainda é pouca, evitei o termo 'peça teatral' ou 'espetáculo', pois poderia gerar uma expectativa de um teatro convencional (tradicional), o que não era a minha proposta. Optei por uma criação que tivesse o improviso como foco e a utilização de vários espaços da escola. Além da utilização do sistema de Spolin (2003), desenvolvi certos jogos de Boal (2005), da obra 'Teatro do Oprimido e outras poéticas políticas'.

Em princípio, tive receio que o conteúdo político da 'Experiência Teatral' ficasse em primeiro plano e tornasse a forma pouco expressiva, ou mesmo que os procedimentos de criação por meio do improviso não fossem assimilados pelos alunos, atrapalhando a aprendizagem da linguagem teatral. Mas, em conversas após a iniciativa, os alunos relataram que 'aprenderam um novo jeito de fazer teatro', o qual eles não imaginavam que era possível. De qualquer maneira, a minha preocupação inicial se diluiu quando compreendi que "[...] todo teatro é necessariamente político, porque políticas são todas as atividades do homem, e o teatro é uma delas" (BOAL, 2005, p. 11). 


\section{O roteiro cênico}

O roteiro cênico apresentado aos alunos tinha quatro elementos básicos que sustentavam a improvisação dos jogadores: um personagem que guiava o jogo, interpretado por três alunos em momentos distintos e chamado 'R.P.' (Representante do Poder); a utilização de vários espaços da escola (portão de entrada, corredores, pátio, escadas e sala de aula); as propostas de jogo que serviam como estímulo para a improvisação dos alunos; a profanação dos dispositivos de controle. Lembrando que segundo Agamben (2009) profanar é devolver ao uso comum aquilo que foi separado na esfera do sagrado, é dar um novo uso, propus no roteiro cênico que meus alunos dessem um 'novo uso' aos dispositivos presentes na escola, usando o que não podiam ou usando de um novo jeito, brincando e colocando a plateia ${ }^{2}$ no lugar do aluno (gerando a profanação da postura dos professores). Antes de iniciarmos a experiência, propus aos meus alunos que nossa abordagem não fosse de ataque, mas sim de reflexão.

Apresento, a seguir, a descrição das cenas finalizadas do que nomeei 'Experiência Teatral':

1. No portão de entrada lateral

O Representante do Poder, 'R.P.', usando um boné, dá ordens ao público: explica o que devem fazer e como devem agir durante a 'Experiência Teatral'; verifica se as roupas do público são apropriadas; verifica se tem alguém de boné e se tiver repreende; verifica se o público possui celular e novamente o repreende.

O 'R.P.' exige que o público entre de uma só vez pelo corredor estreito e dá poucos segundos para que essa ação ocorra. No fim do corredor os outros jogadores recebem o público em festa, aos gritos de 'Aqui é o seu espaço'. No alto de um murinho o 'R.P.' diz proibições à plateia, como por exemplo: 'não pode falar', 'não pode caminhar relaxadamente', 'não pode chupar bala ou chiclete', 'não pode rir', 'não pode se dispersar', e emenda: 'Nós só estamos pensando no seu bem-estar'. O 'R.P.' é interpelado por um jogador que pergunta 'Por que?', mas ele foge de uma resposta. No caminho para se chegar ao pátio, os jogadores formam uma corrente com os braços para que a plateia não ultrapasse os limites espaciais. Chegando ao pátio, os jogadores dão gritos ensurdecedores, simulando um sinal, e se jogam no chão se debatendo. O 'R.P.' manda os espectadores entrarem um por vez e distribui números

\footnotetext{
2 A plateia foi composta por professores, alunos, pais e amigos de alunos, por uma funcionária, pela coordenadora pedagógica da escola e pela diretora da unidade escolar.
} 
a eles. Ao entrar na área próxima às escadas, a plateia encontra cadeiras numeradas, e deve sentar naquela que for referente ao número que ganhou. O 'R.P.' diz que agora a plateia pode relaxar um pouco e avisa que na próxima cena conheceremos o novo 'R.P.'

\section{Na Escada}

O grupo maior de jogadores se posiciona na escada esquerda, enquanto três jogadores se posicionam no vão livre da escada. Os jogadores do grupo maior tentam subir ao mesmo tempo pela escada esquerda. Reclamam, brigam e se empurram. Um jogador decide descer e subir pela escada direita. Os jogadores o aconselham a não fazer isso. O jogador se dirige à escada direita e fica deslumbrado com o que vê: senta na escada, deita, tateia os degraus e o corrimão. Os jogadores da escada esquerda observam. Simultaneamente a essa ação, no vão da escada, um jogador narra um trecho do 'Mito da Caverna', de Platão, enquanto os outros dois, com lanternas, brincam de fazer sombras nas paredes.

Na escada direita, um tapete vermelho é lançado escada abaixo. O jogador que ocupou a escada é coroado com um boné e usa o tapete como manto. Enquanto ocorre essa ação, uma jogadora, no vão da escada, narra um trecho de 'O Príncipe', de Maquiavel.

O jogador coroado se torna o novo 'R.P.' (Representante do Poder) e ordena que todos os jogadores ocupem a escada direita, enquanto, a plateia, deve subir pela esquerda.

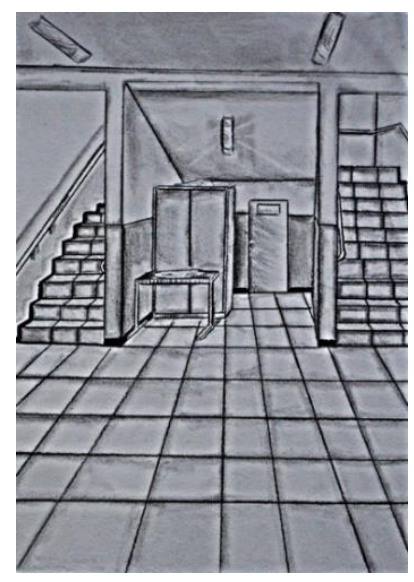

Figura.01 - Desenho da escada da escola feito pela Aluna J, 14 anos, 90. A.

Fonte: Acervo pessoal. 


\section{Nos corredores}

O 'R.P.' pede ao público que se concentre próximo ao corredor que dá acesso às salas de aula, para assistir à cena que segue. Os jogadores ocupam o corredor da maneira que desejarem: dançando, cantando, correndo, brincando, usando o celular para ouvir música, tirar fotos, etc.

Após alguns minutos, o 'R.P.' manda os jogadores pararem suas ações e é interpelado por um jogador que pergunta 'Por que?', mas ele foge de uma resposta. Ordena que os jogadores formem uma fila, inclusive que a plateia faça parte dela. Marchando, a fila segue em direção a uma sala de aula. No caminho, sem que o 'R.P.' veja, os jogadores param de marchar e criam outros gestos. Ao chegar na sala, o 'R.P.' se despede de sua função.

\section{Na sala}

Ao entrar na sala, a plateia se depara com um ' $U$ ' de cadeiras e com o novo 'R.P.', de boné, sentado em uma escada, de frente para as cadeiras. O público é orientado pelos jogadores a ocupar as cadeiras. O novo 'R.P.', do alto da escada, reclama de tédio e ordena que os jogadores Ihe promovam diversão. Um jogador sugere o 'concurso do boné': um ao lado do outro, os jogadores possuem embaixo do boné algum objeto (um pen-drive, uma minibíblia, um bombom) que o 'R.P.', ou mesmo alguém da plateia, deve adivinhar o que é.

Após a realização desse jogo, o 'R.P.' propõe o jogo das 'formas no espaço': o 'R.P.' diz uma forma ou uma letra que os jogadores devem formar com o corpo, coletivamente. O 'R.P.' dá palpites e diz onde cada um deve se posicionar.

Em seguida, o 'R.P.' ordena outro jogo. Trata-se do 'Teatro-Imagem' de Augusto Boal. Nele os jogadores devem criar corporalmente uma imagem real da escola e uma imagem ideal.

Na última proposição, o 'R.P.' manda que a plateia copie em um papel o que os jogadores irão escrever. Na verdade, os jogadores farão em uma cartolina repetidas linhas onduladas, as quais a plateia deverá reproduzir no papel. Na sequência, o 'R.P.' exige que a plateia escreva no papel o que entendeu do 'texto' (na verdade as linhas onduladas). 
No final dessa cena, o 'R.P.' demonstra muita insatisfação com tudo e resolve dormir, sentado em sua escada. Dois jogadores estendem na sua frente um lençol branco, que servirá de tela para a projeção de um vídeo feito com os alunos da sala, no qual eles relatam situações do cotidiano escolar.

\section{Considerações}

Iniciei esta pesquisa motivada por uma inquietação em relação aos dispositivos de controle presentes na escola, mais particularmente, por uma indignação pela regra que restringe $o$ acesso dos alunos. Parti da pergunta: como fazer resistência a tantos dispositivos presentes no cotidiano escolar? A hipótese era de que o teatro poderia resistir a esses dispositivos.

Realizei conversas não diretivas com uma sala de $9^{\circ}$. ano no intuito de observar se as minhas inquietações eram também as inquietações de meus alunos, no que concerne ao cotidiano escolar. Pela escuta sensível, notei que havia uma série de dispositivos que interferiam na vida dos estudantes. Por isso, optei por inserir em nossa proposta todos os dispositivos que tinham sido listados pelos estudantes e, portanto, não só a escada. Propus então uma prática com o sistema de jogos teatrais de Spolin $(2003 ; 2007 ; 2008)$ que tivesse como conteúdo as regras e proibições da escola, a qual chamamos 'Experiência Teatral'.

Utilizei a definição de Agamben (2009, p. 40) acerca do dispositivo, - "[...] qualquer coisa que tenha de algum modo a capacidade de capturar, orientar, determinar, interceptar, modelar, controlar e assegurar os gestos, as condutas, as opiniões e os discursos dos seres viventes" - por abarcar a linguagem. Ainda que seja um dispositivo, a linguagem, na visão do filósofo, possui um potencial profanatório. A 'profanação' é para Agamben (2009) o contradispositivo que restitui ao homem aquilo que Ihe foi separado pela esfera do sagrado, possibilitando um novo uso. Considerei que o teatro, sendo uma linguagem e, portanto, um dispositivo, poderia configurarse em um contradispositivo.

Durante a 'Experiência Teatral', enquanto subíamos as escadas, a diretora da escola comentou que não entendia por que a 'regra da escada' havia sido instituída pela gestão anterior. Ocorre que a regra ainda existe.

Isso seria um indício de que nossa proposta teatral não obteve resultado? Aqui cabe refletir sobre o nosso objetivo principal: a resistência pela profanação dos dispositivos. 
O foco da minha pesquisa é o aluno. Seria ingênuo supor que a 'Experiência Teatral' transformaria as regras da escola e que, professores, funcionários e gestores lançariam mão de proibições que Ihes são tão cômodas. Assim, eu não contava com a anulação da regra. O meu interesse era em brincar com a norma, por isso o uso do jogo teatral. Tencionava um novo uso dos dispositivos, por essa razão a profanação. O movimento devia se dar no aluno. Para tanto, era necessário que o aluno refletisse sobre o seu entorno e sobre a presença dos dispositivos.

Na primeira abordagem que fiz com meus alunos, surpreendeu-me o fato de que eles se mantiveram em silêncio e tiveram dificuldade de expressar suas inquietações sobre o cotidiano escolar. Falar sobre como se sentiam na escola, foi o primeiro passo para a reflexão. No segundo momento, a dramatização possibilitou-Ihes questionar a existência dos dispositivos. Em cena, eles diziam 'Por que?'. Por último, o relato da experiência vivida revela um novo pensamento sobre o cotidiano, agora imbuído de indagações. Tal movimento evidencia-se na fala dos alunos, pós 'Experiência Teatral':

Eu gostei da cena em que a jogadora ficava dizendo 'Por que?', porque eu acho que a gente tem que mostrar para as pessoas que a gente tem que questionar (Aluna $G$, 14 anos, 90. A).

Eu achei uma forma diferente de se expressar (Aluno H, 14 anos, 90. A).

Não só pelo fato de eu conseguir me expressar melhor, mas eu acho que eu era uma pessoa que tinha muitas ideias, mas ficava muito na minha. Eu acho que eu consegui me soltar mais para ter opiniões, mesmo que seja diferente. Posso criar alguma coisa que as pessoas entendam no sentido positivo, que elas possam entender (Aluna $A$, 14 anos, 90. A).

E é justamente porque o 'Por que?' traz a sabedoria. E eles não querem que a gente saiba demais (Aluno B, 14 anos, 90. A).

A gente esqueceu um pouco de questionar, porque a gente ficou nessa de 'disciplinamento'. A gente sabia que se a gente falasse um 'Por que?', a gente não teria resposta, então a gente deixou de fazer o 'Por que?'. Depois dessa peça, a gente abriu os olhos. Vamos fazer mais 'Por que?' (Aluna A, 14 anos, 90. A).

Conhecer-se melhor e problematizar a realidade são ações que a Arte pode provocar. De acordo com Perissé (2009, p. 61) "Do ponto de vista didático, conduzir os alunos à realização de uma peça teatral [...] pressupõe fazer com que cada um se conheça melhor" e ainda "[...] visualizamos melhor nossos impasses e conflitos quando 
dramatizados" (p. 63). Para o autor, nesse processo descobrimos caminhos de humanização, porque a arte "[...] abre caminhos onde não há caminhos" (p. 87).

Para Perissé (2009, p. 83) o professor deve trabalhar com Ética e Estética, ou melhor, "(Est)eticamente". Segundo o autor, eticamente o docente precisa "[...] investigar os princípios e os valores que devem orientar as ações humanas, descobrindo formas de suscitar essa reflexão entre os alunos" e esteticamente deve "[...] despertar em si e nos demais a reflexão sobre a arte, relacionando-a com tantos outros temas". Assim, (est)eticamente, "[...] cabe ao docente inventar formas belas-boas de pensar e agir".

A escada é o objeto sagrado. Ela separa deuses dos homens. Mais do que possuí-la é necessário atribuir-Ihe um novo uso, como também, compreender porque ela existe na forma de um dispositivo. Segundo Agamben (2006) a essência do pensamento é a potência, que se define pela possibilidade do seu não-exercício, de uma não passagem ao ato. Trata-se de 'poder não-possuir'.

\section{Referências}

AGAMBEN, Giorgio. Estado de exceção: homo sacer, II, I. São Paulo: Boitempo, 2004.

. A potência do pensamento. Revista do Departamento de Psicologia UFF. Niterói, v.18 - n.1, p. 11-28, Jan/Jun, 2006.

Profanações. São Paulo: Boitempo, 2007.

O que é o contemporâneo? E outros ensaios. Chapecó, SC: Argos, 2009.

BARBIER, René. A pesquisa-ação. Brasília: Liber Livro Editora, 2007.

BOAL, Augusto. Teatro do oprimido e outras poéticas políticas. Rio de Janeiro: Civilização Brasileira, 2005.

FOUCAULT, Michel. Microfísica do poder. 12 ed. Rio de Janeiro: Edições Graal, 1979.

.História da sexualidade I: a vontade de saber. 11 ed. Rio de Janeiro: Edições Graal, 1993.

Vigiar e Punir. 29 ed. Petrópolis: Vozes, 2004.

Revista Digital do LAV - Santa Maria - vol. 11, n. 1, p. 31-53-jan./abr. 2018 ISSN 1983 - 7348 
MILSTEIN, Diana; MENDES, Héctor. Escola, corpo e cotidiano escolar. São Paulo: Cortez, 2010.

MUCHAIL, Salma T. Foucault, simplesmente. São Paulo: Edições Loyola, 2004.

PERISSÉ, Gabriel. Estética e Educação. Belo Horizonte: Autêntica, 2009.

SPOLIN, Viola. Improvisação para o teatro. 4 ed. São Paulo: Perspectiva, 2003.

\footnotetext{
i Mestre em Educação pelo Programa de Pós-Graduação em Educação, da Universidade de Sorocaba (UNISO), possui Especialização em Pedagogia do Teatro e Graduação em Teatro / Arte-Educação pela Universidade de Sorocaba (UNISO); é docente do Instituto Federal de Educação, Ciência e Tecnologia de São Paulo, no Câmpus Boituva, em regime de dedicação exclusiva, atuando nos âmbitos do Ensino, Pesquisa e Extensão; ministra aulas de Arte para o Ensino Médio Integrado e para a Licenciatura em Pedagogia; desenvolve projetos nas áreas de Ensino de Teatro, Arte e Jogos e Brincadeiras.
}

Como citar esse artigo:

ALMEIDA, Patrícia Neves. A profanação dos dispositivos escolares e o jogo teatral. Revista Digital do LAV, Santa Maria: UFSM, v. 11, n. 1, p. 31-53, jan./abr. 2018.

Enviado em: 22 de outubro de 2017

Aprovado em: 02 de fevereiro de 2018. 